\title{
Badminton Smash Basic Training Model
}

\section{*Ade Rahmat ${ }^{\text {labcde }}$}

${ }^{1}$ Pendidikan Jasmani, Kesehatan Dan Rekreasi IKIP PGRI Pontianak, Indonesia.

\section{A B S T R A C T}

A R T I C L E I N F O

\begin{abstract}
The purpose of the study. This study aims to develop a basic training model for badminton Smash in badminton athletes in West Kalimantan.

Materials and methods. The method used in this study is research and development modifying the Borg and Gall model.

Results. The results of this study indicate that the badminton smash basic training model can be said to be valid from the study and assessment by experts.

Conclusions. And the development of basic badminton smash training model is categorized as feasible to be used in badminton smash training because the developed smash model can be a smash training model that requires hand skills and strength, so the Badminton Smash Basic Training Model is recommended as a training model that can provide new nuances in apply a good smash.
\end{abstract}

Keywords: Exercise Model; Smash; Training; Badminton.

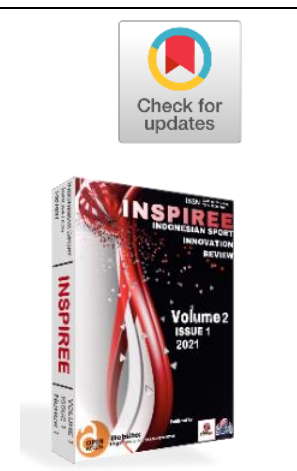

Article History:

Received: May 31, 2021 Accepted: July 02, 2021

Published: September 27, 2021

\section{INTRODUCTION}

Badminton is one of the famous sports in Indonesia. This sport attracts various age groups, various skill levels, and both men and women play this sport indoors or outdoors for recreation as well as competition. Badminton shuttlecock is not reflected on the floor and must be played in the air, so this game is a fast game that requires good reflexes and a high level of fitness (Li, Shiming, 2017), (Akbari, Myrza, Firmansyah Dlis, and Widiastuti, 2018). Badminton is a sport that belongs to the game sports group. Badminton can be played indoors or outdoors, on a restricted field with lines of a certain length and width. Badminton sports are played on a field that is limited by lines of a certain length and width. The field divided into two is equal and separated by a net stretched on both net posts planted on the edge of the field (Khan, Shahzaman, et al, 2017). 
A badminton player must master a variety of techniques or tactics that support badminton. The first step to becoming an accomplished player is to master the basic variety of badminton games correctly. Therefore, with capital practicing diligently, disciplined, and directed under the guidance of a qualified coach, players can master various basic techniques of playing badminton correctly (Widiastuti, W., Imran, I., \& Pradityana, K, 2019). Mastery of these basic techniques includes how to hold a racket, wrist movements, footsteps or footwork, and concentration or concentration. After mastering basic techniques, a player is expected to be able to master punch techniques. One punch technique in sports that is widely used to attack and kill the opponent's movements is a smash punch. This blow is one of the hard shots to master, it needs to be hard and intensive training so that the smash can hit the target correctly (Zhang Zhao 2015), Rusydi, Muhammad Ilhamdi, et al (2015).

Mastery of basic techniques is something that needs to be developed for game performance. The basic badminton technique must be thoroughly studied first, in order to develop the quality of badminton achievement because winning or losing a player in a match is one of them determined by the mastery of the basic techniques of the game. The basic techniques that must be mastered by a badminton player are: (1) How to hold the racket, (2) Adjustment of foot movements, (3) Mastery of punches, (4) Type of play (Yüksel, Mehmet Fatih, and Latif Aydos, (2018), Firmansyah (2013).

In addition to the other blows, smash is a blow that is commonly used because it is very possible to suppress the opponent's game so that the opponent must always be ready and deft in anticipating it. According [9] Smash blows are overhead blows (above) which are directed downward and carried out with full force. One of the most widely used punch techniques in sports to turn off the opponent's game is a smash (Tan, D. Y. W., H. Y. Ting, and S. B. Y. Lau, 2016). Smash blows are hard overhead blows, directed down strong, are the main attacking blow in badminton (Shan, CZ, Ming, ESL, Rahman, HA, \& Fai, YC, 2015). In addition, Creado, Shane (2018) states that a smash is a quick hit, directed down strongly and sharply to return a short ball that has been hit upwards. A smash punch is an over head punch that relies on the strength and speed of the arm (Benovri, Ridho, 2018). 
Among all of these techniques, smash blows are the hardest and fastest attacking blow from the stroke technique of playing badminton. What is meant by hitansmash is A quick blow, directed down firmly and sharply to return a short ball that has been hit upwards (Purnama K Sapta 2010) To be able to master the smash stroke technique it is necessary to have continuous practice and be supported by high stamina or physical conditions prime. Without the mastery of high-level techniques and continuous practice it is impossible to master smash blows properly. Smash blows have an important meaning that can give the opponent a little time to get ready or return each short ball they have hit up. This shows the more sharp the direction of the blow, the less time the opponent has to react. But in reality on the field not a few coaches give less attention to the children trained to do targeted smashes (target targets). Even though in badminton games, directed smashes are very important for the players. A direct smash hit makes it easy to turn off your opponent. If the mastery of smash is not good means that the player will be difficult to turn off the opponent. Advanced players can usually do targeted smashes, then the player can control the course of the match (Grice, T, 2018).

Furthermore, the technique of beating badminton that must be mastered is as follows: service punches, lob or clear blows, dropshot blows, smash blows, drive blows or horizontal and return service or return service. One technique for getting points or numbers is smash (Awatani, Takenori, et al, 2018). Smash is "a hard overhead blow, directed down strong, is the main attacking blow in badminton". To be able to win a match, players must have good competitiveness. One technique for winning games is smash (Lam, Wing-Kai, et al, 2018). By doing a hard hit and aiming it will make it difficult for your opponent to return the punch. Smash blows are a form of hard punch that is often used in badminton games. The character of this punch is the hard and fast pace of the shuttlecock towards the ground floor. This blow requires leg muscle strength, shoulders, arms, wrist flexibility, and harmonious gesture coordination (Chen, Lung-Ming, Yi-Hsiang Pan, and Yung-Jen Chen, 2009).

Based on the description above, it is necessary to develop a basic model of badminton smash training aimed at contributing to the knowledge and development of playing badminton. 


\section{MATERIALS AND METHODS}

\section{Study participants}

This study aims to develop a basic training model for badminton Smash in badminton athletes in West Kalimantan

\section{Study organization}

The method used in this study is research and development modifying. Anasir, Saleh (2010). Research and Development is an educational research and development process used to develop and validate educational products. Development research includes the process of finding newness and excellence in the framework of the effectiveness of the basic Smash badminton training model. The procedure used in this study is the planning stage of the model development and evaluation phase. At the evaluation stage researchers only conducted expert validation tests with the aim of finding out whether the developed badminton Smash basic training model received suggestions and ratings from badminton experts. The results of expert advice will be input to improve the quality of the model developed.

\section{Testing Procedur}

The instrument used in this study is using instruments that have been developed. The data analysis used in this study is using descriptive qualitative data analysis which aims to reveal how the process of developing a basic technical training model while the quantitative data is only to analyze the results of the questionnaire regarding the validation of the smash training model. As for the model validation of the smash criteria, namely: 4.00-3.50 Very Good Criteria, 3.49-3.00 Criteria Good, 2.99-2.50 Criteria Poor. And 2.49-0.00 criteria are not good.

\section{RESULTS}

The results of the development of a basic technique training model for badminton smash is that starting from technical training the overhead blow is carried out with all its might from the top position and swooping directed to the opponent's bottom position. This smash blow is also called an attacking blow because the main goal is to kill the opponent. This smash punch technique is a form of punch that is often used in badminton games. This basic smash punch technique requires aspects of leg muscle strength, shoulders, arms, and wrist flexibility as well as harmonious body movement coordination because the characteristics of this punch are hard and how fast the speed is very fast landing on the floor. In contrast to the netting technique that emphasizes deception with a subtle touch in front of the net. 
In developing this basic smash badminton technique training model there are several techniques that need to be considered to produce the right and quality smash blows in badminton. (1) Note the position of the racket handle (Grip) properly. (2) Move quickly to take the right position for a shot punch. (3) The body's attitude must remain flexible, both knees bent and still concentrate on the shuttlecock. (4) Find the right time / time to punch. (5) The introduction of a racket and shuttlecock is above the head by stretching the arms to reach the highest possible shuttlecock. (6) Use wrist power as quickly as possible when hitting it. (7) End the series of oscillations with lan-jut's swing the perfect racquet in front of the body.

Furthermore, in the development of a training model for the basic techniques of smash badminton there are several types of punches, namely the smash punch technique can be done with a state of silence, standing or while jumping. Some types of smash blows in sports are bad fights that usually occur on the field, among others, full smasher, cut smash, backhand smash, and circular smiles over the head. Gradually each player must master the smash technique perfectly because the benefits are very great for improving the quality of the game. The following is a picture of how to practice basic smash badminton:

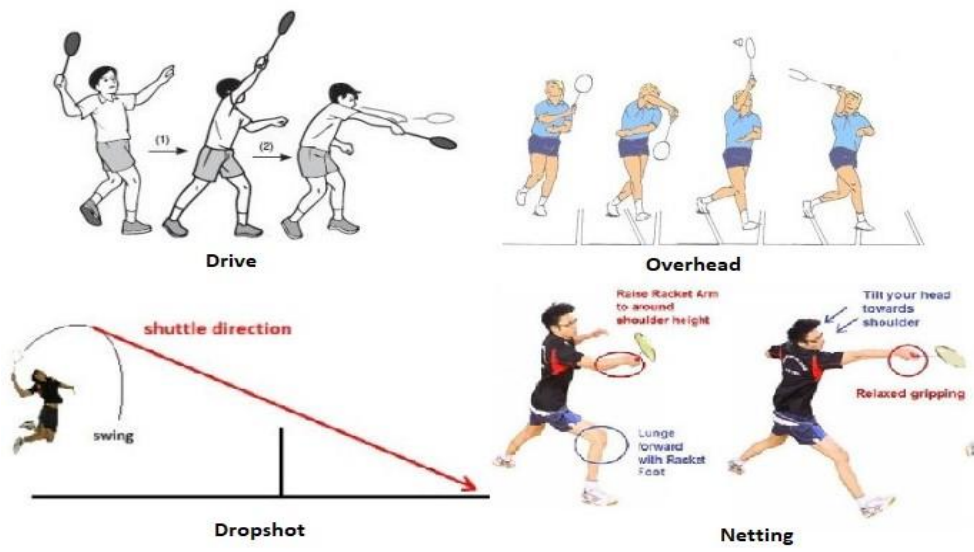

Figure 1. Training techniques for Smash badminton

Basic technical training on how to do a good and correct badminton smash. The smash punch technique is an overhead blow that is carried out in full force from the top position so that the ball (shuttlecock) dives sharply quickly and hard in the opponent's area. smash if it is often referred to as an attacking blow because indeed the main goal of a smash punch is to kill the opponent. The following are the results of the assessment of the validation of a badminton expert can be seen in the following table: 


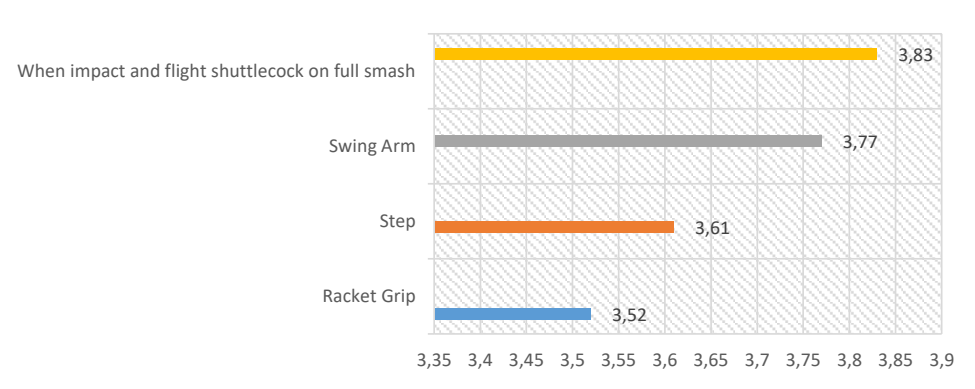

Figure 2. Graphing results from the validation model of the basic Smash Badminton training technique

Based on the assessment of badminton experts, the four aspects of the evaluation of the development of the basic badminton smash training technique model are (1) Racket Grip, the value of 3.52 is categorized as very feasible (2) and flight shuttlecock on full smash was obtained 3.87 categorized as very feasible. Furthermore, there are many aspects that have an effect on the success of smash blows in addition to good and correct mastery of techniques, physical components and two-way drill practice also play a role in the success of smash shots. The actual smash stroke does not merely use the muscle strength of the arm. In making a badminton smash, the speed and accuracy of the wrist slips is the key to how a badminton smash punch can dive sharp and hard.

\section{DISCUSSION}

Based on the findings of the study in this study, it was found that the basic technique of badminton smash training is very necessary to facilitate beginner athletes in learning on the branch by badminton, this basic technique of badminton smash training requires speed and precision of wrist blows to be the main key to how to punch Badminton smashes can dive sharply and hard. The process of the basic technique model of smash training involves three stages, namely the movement to take position, preparation and the last to do the smash itself. Position movement: Footwork is to get the right position in badminton smash, stop and center your balance before hitting. You cannot shoot effectively unless you are in a good position and time. You need time where you will stop and balance your body before trying to do a smash shot. Preparation: The position is ready to pay attention to the position of the grip of the racket (Grip) correctly. Your body must relax - the tense muscles move more slowly than the relax ones. Use the forehand grip (same as in Tennis) to keep the grip relaxed. Next take a step forward when doing a smash. You aim to hit the shuttlecock at the highest point that is comfortable for you - the arms and racket must be fully placed on the point with the biggest smash impact. The findings of this study are supported by 
the results of a study conducted (Salim, M. S., et al 2010) who suggested that smash techniques in badminton are needed to position movements that are ready to smash, when smash athletes must be able to operationalize their hands by having as much power as possible. Furthermore, the findings were also supported (Benovri, Ridho 2018) who stated that if the model of smash training was carried out properly, this model would be effective against the desired smash results.

\section{CONCLUSIONS}

Based on the results of research findings and development of the basic model of badminton smash training, it was found that the results of the experts obtained very feasible use of this category because the basic technique of badminton smash training is the right way to swing the racket, applying perpendicular to the racket leaves with the arrival shuttlecock, so that the blow is carried out in full. The character of this blow is the hard and fast pace of the shuttlecock towards the ground floor. Both straight smashes and cross smashes can both be hit with the same swing. Smash can also be done by jumping. Smash (around the head) smash jumping requires a lot of energy, but it also needs good coordination between the members involved. Furthermore, the researcher informed that this research report was limited to model validation testing, namely the researcher asked for opinions and evaluations by badminton experts about the models developed by us, but this research will have the next stage, namely user testing and testing the effectiveness of the model.

\section{REFERENCES}

Akbari, Myrza, Firmansyah Dlis, and Widiastuti Widiastuti. "The effect at muscle power arm, hand-eye coordination, flexibility and self confidence upon badminton smash skill." JIPES-Journal of Indonesian Physical Education and Sport 4.1 (2018): 57-64

Ahmad Pratama, S. (2021). Impact of Shadow Training on the Ability of Push Forward Punch Techniques in Table Tennis. INSPIREE: Indonesian Sport Innovation Review, 2(1), 08-16. Retrieved from https://www.inspiree.review/index.php/inspiree/article/view/29

Anasir, Saleh. "Hubungan antara ketepatan pukulan smash penuh dan kemampuan bermain bulutangkis pada siswa kelas atas SD Piri Nitikan Yogyakarat tahun 2010." Skripsi: FIK Universitas Negeri Yogyakarta (2010). 
Awatani, Takenori, et al. "Correlation between isometric shoulder strength and racket velocity during badminton forehand smash movements: study of valid clinical assessment methods." Journal of Physical Therapy Science 30.6 (2018): 850-854.

Benovri, Ridho. "Pengembangan Model Latihan Smash Bulutangkis untuk Usia Remaja." Motion: Journal Research of Physical Education 9.1 (2018): 1-10.

Benovri, Ridho. " Development of the Badminton Smash Exercise Model for Youth." Motion: Journal Research of Physical Education 9.1 (2018): 1-10.

Chen, Lung-Ming, Yi-Hsiang Pan, and Yung-Jen Chen. "A study of shuttlecock's trajectory in badminton." Journal of sports science \& medicine 8.4 (2009): 657.

Creado, Shane. "Badminton, Squash, and Tennis." The ISSP Manual of Sports Psychiatry. Routledge, 2018. 81-92.

Firmansyah, Uswan. "Keterampilan Bermain Bulutangkis Ditinjau Dari Unsur Fisik Dominan Dalam Bulutangkis Pada Pemain Tunggal Anak Putra Persatuan Bulutangkis Purnama Surakarta." Jurnal Phederal Penjas 1.1 (2013).

Grice, T. Bulutangkis Petunjuk Praktis untuk Pemula dan Lanjut. Jakarta: Raja Grafindo Persada (2007)

Khan, Shahzaman, et al. "The Affiliation Between Athlete's Physiological And Anthropometrical Parameters And Its Role In Performance Of Male Badminton Competitors." The Shield-Research Journal of Physical Education \& Sports Science. 11 (2017).

Lam, Wing-Kai, et al. "Understanding the impact loading characteristics of a badminton lunge among badminton players." PloS one 13.10 (2018): e0205800.

$\mathrm{Li}$, Shiming, et al. "The relevance of body positioning and its training effect on badminton smash." Journal of sports sciences35.4 (2017): 310-316.

Rusydi, Muhammad Ilhamdi, et al. "Local Euler angle pattern recognition for smash and backhand in badminton based on arm position." Procedia Manufacturing 3 (2015): 898-903.

Poole, James. Belajar Bulutangkis. Bandung: Pionir Jaya (2008)

Purnama K Sapta.Kepelatihan Bulutangkis Modern. Surakarta:Yuma Pustaka (2010).

Rizky, V. ., Damanik, S. ., \& Siregar, S. (2021). Inclusion Teaching Style in Improving Learning Outcomes of Forehand Drive Table Tennis in Junior High 
School. INSPIREE: Indonesian Sport Innovation Review, 2(1), 53-72. Retrieved from https://www.inspiree.review/index.php/inspiree/article/view/33

Salim, M. S., et al. "Motion analysis of arm movement during badminton smash." Biomedical Engineering and Sciences (IECBES), 2010 IEEE EMBS Conference on. IEEE, 2010.

Shan, CZ, Ming, ESL, Rahman, HA, \& Fai, YC (2015, Mei). Investigasi gerakan tungkai atas selama smash bulutangkis. Dalam Konferensi Kontrol (ASCC), 2015 Asia 10 (hal. 1-6). IEEE.

Tan, D. Y. W., H. Y. Ting, and S. B. Y. Lau. "A review on badminton motion analysis." Robotics, Automation and Sciences (ICORAS), International Conference on. IEEE, 2016

Widiastuti, W., Imran, I., \& Pradityana, K. (2019, January). Improving StudentsBadminton Smash Skill Through Game Modifications. In International Conference on Islamic Education (IColE 2018). Atlantis Press.

Yüksel, Mehmet Fatih, and Latif Aydos. "The effect of shadow badminton trainings on some the motoric features of badminton players." Journal of Athletic Performance and Nutrition 4.2 (2018).

Zhang, Zhao. The influence of body positioning, trunk rotation ( $\mathrm{x}$-factor) and training effect on quality of the badminton forehand overhead smash. Diss. Lethbridge, Alta.: University of Lethbridge, Dept. of Kinesiology and Physical Education, 2015. 


\section{LAMPIRAN}

\section{Information About The Authors:}

\section{Dr. Ade Rahmat, M.Pd:}

Email: Mradde16@gmail.com; Pendidikan Jasmani, Kesehatan Dan Rekreasi IKIP PGRI Pontianak, Jalan Ampera No. 88 Pontianak, Kalimantan Barat, 78116, Indonesia. 